\title{
Management of Cucumber Downy Mildew Caused by Pseudoperonospora Cubensis with use of Benomyl, Plant Extracts and Intercropping
}

\author{
M. J Falade* \\ Department of Crop, Horticulture and Landscape Design, Ekiti State University, Ado-Ekiti, Nigeria
}

*Corresponding Authors: M. J Falade, Department of Crop, Horticulture and Landscape Design, Ekiti

State University, Ado-Ekiti, Nigeria

\begin{abstract}
Downy mildew, caused by Pseudoperonospora cubensis is responsible for about $40 \%$ yield loss of cucumber in Nigeria. Chemical fungicides for its control often cause accumulation of toxic residues in soil, development of fungicide resistance in pathogens and adverse effects on soil and beneficial micro-organisms. This study investigated the effects of hot water leaf extracts of three plants; Datura stramonium, Ricinus communis and Sida acuta at three concentrations (65, 50 and $30 \%)$ in the management of downy mildew disease of cucumber. In the field experiment, cucumber variety (cu999) was intercropped with maize (SUWANESR) and inoculated with conidia suspension of Pseudoperonospora cubensis two weeks after planting. After 48 hours, inoculated plants were sprayed with three different concentrations of D. stramonium, R. communis and $S$. acuta extracts in a randomized complete block experiment. Benomyl (synthetic fungicide) was applied as a check at the rate of $0.1 \mathrm{~g}$ per litre. Data collected were subjected to Analysis of Variance and means separated using Least Significant Difference ( $p<0.05)$. Results from the study shows that, all the extracts significantly reduced $(p<0.05)$ disease spread and the greatest control occurred at $65 \%$ concentration for all the extracts used in the study. At $65 \%$ concentration with extract of D. stramonium, disease incidence for both the sole and intercropped cucumber were $22.6 \%$ and $14.10 \%$ compared to the control (100\%). Cucumber yield in the cucumber-maize intercrop was significantly higher than the sole cucumber at all the tested concentrations. At 65, 50 and 30\% concentration with extract of R. communis, yield of cucumber in the sole crop were $271 \mathrm{~kg}, 268 \mathrm{~kg}$ and $256 \mathrm{~kg}$ while that of intercropped were $320 \mathrm{~kg}, 296 \mathrm{~kg}$ and $285 \mathrm{~kg}$ respectively. Seed germination and fungal infection were generally low in the intercropped and sole plant. Seed germination for sole plant at $50 \%$ concentration with extract of S. acuta was $22.55 \%$ while that of intercropped was $24.52 \%$. The study concluded that the extracts have the potential for the control of downy mildew in cucumber and can replace synthetic fungicide in the management of the disease. In addition, intercropping maize with cucumber can reduce incidence and severity of downy mildew with increase yield.
\end{abstract}

Keywords: Pseudoperonospora cubensis, Cucumber, plant extracts, intercropping

\section{INTRODUCTION}

Cucumber (Cucumis sativus), is a widely cultivated plant in the gourd family, Cucurbitaceae. It is a creeping vine and widely grown in the temperate and warm regions where it provides a major source of vegetables for man, it is also useful in body rehydration and also aids digestion (Ademe et al., 2013). Cucumbers are a valuable source of conventional antioxidant nutrients including vitamin $C$, beta-carotene, and manganese. It is acknowledged that increased agricultural productivity would help in attaining the needed food security. The estimated world cucumber production in 2018 was 83.7 million tonnes with china accounting for $77 \%$ of the output (64.8 million tonnes) (FAO, 2016). West Africa especially Nigeria, Egypt, Ghana and Niger are the key cucumber producing countries while Egypt is the largest producer of cucumber in this area accounting for about 488,723 tonnes (FAOSTAT 2017). Nigeria produces about 27,000 tonnes as at 2017, this output is low due to some limiting factors which hinder production (FAO, 2016). Cucumber is the fourth most cultivated vegetable in the world and is known to be one of the best foods for body's overall health (Natural News, 2014). Cucumber is native to tropical regions of southern Asia, having been cultivated in India for over 3,000 years.

In Nigeria, cucumber production has not been ranked; it is grown mainly in Jos, Kano, Kaduna and Jigawa States. Cucumber does well on well-drained fertile soils with pH 6.0 -7.0 and ample richness 
in organic matter (Nor-Farah et al., 2018). It is often planted on raised beds and thrives in sandy loam soils. The crop requires a good amount of sunshine, warmth and is sometimes grown in green houses. In spite of the increasing relevance of cucumber, low yields are obtained in farmer's farms and its production areas in southeastern Nigeria, this is due to scarcity of planting seed, lack of capital, climatic factors, plant pests and diseases, high fruit perishability and lack of production experience (Jeffery, 2001).

Downy mildew of cucumber is caused by the fungus Pseudoperonospora cubensis. It is a serious fungal disease of cucumber as it is capable of causing significant loss of fruit quality and yield of about 40\% in Nigeria (Wasila et al., 1993). The disease affects mostly the leaves. Symptoms include angular chlorotic lesions on the foliage. These lesions appear angular because they are bound by leaf veins. Magnification of the sporulation reveals the acutely and dichotomously branched sporangiophores bearing lemon-shaped sporangia. Eventually, leaves will turn necrotic and curl upwards. The disease is sometimes called wildfire because of how rapidly it progresses, as if the crop were burned by fire (Adedipe, 2017)

This disease can be controlled effectively by the use of resistant varieties, where they exist, use of protectant and systemic fungicides, fungicides are more effective when applied prior to infection and reapplied at 5-7 day's intervals (Alves et al., 2015). However, due to the side effects of these synthetic fungicides and the cost, much attention has been focused on the alternate methods of pathogen control like the use of plant extracts (Amadioha, 2003). Extracts obtained from plants are cheap, readily available and compatible with the farming practices of the farmers. In addition, it has no residual effect on soil and environment (Lowell, 2014). Leaf extracts of plants such as Jimson weed (Datura stramonium), castor oil (Ricinus communis), Ironweed (Sida acuta) have been used for the control fungal infections in various plants. However, its use in the control of cucumber anthracnose has not been tested. Based on the above, experiment was conducted to test the efficacy of the three plant extracts in the control of downy mildew of cucumber caused by Pseudoperonospora cubensis.

\section{Materials ANd Methods}

\subsection{Location of experiments}

Laboratory studies and field experiments was conducted at Ekiti State University Teaching and Research farm $\left(7.7129^{\circ} \mathrm{N}, 5.2523^{\circ} \mathrm{E}\right)$, Ado Ekiti, Nigeria.

\subsection{Preparation of laboratory apparatus}

Glasswares used in the studies were washed with detergent containing $0.05 \%$ sodium hypochlorite for 30 minutes, rinsed with tap water and dried inside an oven at $50^{\circ} \mathrm{C}$ for $2 \mathrm{hrs}$. After, Erlenmeyer flasks, Petri-dishes, glass pipettes, beakers were wrapped in aluminum foil and sterilized in oven for 35 minutes. Inoculating loop, cork borers and scalpels were sterilized by dipping in $70 \%$ ethanol and flaming to red hot before and after use. Laminar flow cabinet and all other working surfaces were disinfected by swabbing with $70 \%$ ethanol. Sterile distilled water was used in the study.

\subsection{Preparation of media}

Potato Dextrose Agar (PDA) was prepared by dissolving 39g dehydrated PDA in 1L of sterile distilled water in an Erlenmeyer flask. The flask was stopped using cotton wool plug, wrapped with aluminum foil and autoclaved at $121^{\circ} \mathrm{C}$ for 15 minutes at pressure of $100 \mathrm{kpa}$. Agar was allowed to cool to room temperature $\left(45^{\circ} \mathrm{C}\right)$ and amended with $300 \mathrm{mg} / \mathrm{L}$ streptomycin sulphate and $20 \mathrm{ml}$ of cooled media were poured into $9 \mathrm{~cm}$ diameter sterile Petri dishes (Sterilin Product, UK) inside a laminar flow cabinet and allowed to solidify.

\subsection{Collection and preparation of plant materials (leaves)}

Leaves of the three plants namely; D. stramonim (Linn), R. communis (Linn) and S. acuta (Burm.f.) were collected at Ekiti State University, Ado Ekiti and air-dried at $28^{\circ} \pm 2^{\circ} \mathrm{C}$ for 5-6 weeks to constant weight. Dried leaves were milled using a blender (Okapi, Mixed-Grinder), packaged into sealable nylon and refrigerated at $4^{\circ} \mathrm{C}$ for 2 weeks (until they were required for bioassay).

\subsection{Preparation of plant extracts}

Extracts were prepared by mixing equivalent grams of prepared plant powder $(65,50$ and 30) with $100 \mathrm{ml}$ of distilled hot water maintained at $70^{\circ} \mathrm{C}$ in $500 \mathrm{ml}$ bottles and kept in hot water bath-shaker for 30 minutes. Thereafter, the liquid extract was separated by using two folds cheese cloth and poured 
inside standard bottles which were refrigerated at $4^{\circ} \mathrm{C}$. These extracts were used as the stock solution from which $65 \%, 50 \%$ and $30 \%$ of each extracts were prepared.

\subsection{Isolation and identification of Pseudoperonospora cubensis}

Cucumber plants showing distinct symptoms of the disease were collected from the cucumber fields. Leaves were cut into small pieces $(1-2 \mathrm{~cm})$ and surface sterilized by immersion in $0.2 \% \mathrm{NaOCl}$ for 2 minutes, and rinsed in two changes of sterile distilled water. Three leaf cuttings $(1 \mathrm{~cm})$ per plate were placed on PDA. The plates were sealed with parafilm tape and incubated at $28^{\circ} \mathrm{C}$ for $5-6$ days. Single spore of developing colonies was isolated and sub-cultured to obtain pure cultures. Samples from single spore cultures were used for morphological identification on agar at $\mathrm{x} 400$ magnification of a compound microscope (Zivkovic et al., 2010)

\subsection{Maintenance and storage of culture}

Pure culture of Pseudoperonospora cubensis were either maintained on PDA agar slants in McCartney bottles secured with a screw cap for short-term storage (1-2 weeks) at $4^{\circ} \mathrm{C}$ or stored in $20 \%$ aqueous glycerol and refrigerated for long term preservation (1-3 months) at $4^{\circ} \mathrm{C}$.

\subsection{Field Experiment}

Cucucmber seeds variety (Cu999) was intercropped with maize (variety: SUWAN-ESR). Hot water extracts of D. stramonium, $R$. communis, $S$. acuta were applied as foliar spray. The 2 x 3 x 3 factorial experiment was a split plot design and two cropping systems were used: (a) sole cucumber (which was the control) and (b) cucumber intercropped with maize. The plot size was $2 \mathrm{~m}$ x $2 \mathrm{~m}$, separated by boarder row $1 \mathrm{~m}$ and the total are of the plot was $160 \mathrm{~m}^{2}$. the total population of cucumber in each cropping system was 495 stands and population of maize in the cucumber-maize intercrop was 96. Cucumber was planted at 2 seeds hole ${ }^{-1}$ at a spacing of $60 \mathrm{~cm} \times 30 \mathrm{~cm}$ and the intercropped maize was planted at a spacing of $60 \mathrm{~cm} \times 90 \mathrm{~cm}$. Two surface sterilized seeds of each variety of cucumber and maize was sown, and seedlings. Seedlings were thinned to one per stand after germination. Two weeks after planting establishment, the cucumber were sprayed with Pseudoperonospora cubensis conidia suspension containing $10^{4}$ conidia $\mathrm{ml}^{-1}$ while the control was sprayed with sterile distilled water. Incidence and severity of downy mildew disease was monitored and recorded. After maturity and harvesting, fifty randomly selected fruits were examined and separated into normal and abnormal fruits. The abnormal fruits were those with malformed shape, wringled seed coat or those bearing fungal propagules. Twenty seeds each were placed on the petridish and incubated in Gallenkamp growth chamber for seven days under alternating cycles of twelve hours light and darkness. Evidence of fungal infection were observed on the seeds with the aid of stereo microscope and identification of the fungus was based on the hyphal and conidial characteristics. Germinated seeds were expressed as a percentage of the total number of seeds. Percentage of disease incidence was determined using the formula

Didease incidence $=\frac{\text { Number of plant infected } X 100}{\text { Total number of plants }}$

Data obtained were analyzed using ANOVA and treatment means were separated using Turkey Significant Honest Test

\section{RESULTS}

\subsection{Effect of Plant extracts, concentrations and Intercropping on Incidence of cucumber Inoculated with Pseudoperonospora cubensis}

Table 1 shows the effect of plant extracts and concentrations on incidence of downy mildew of cucumber. Disease incidence varies with the concentrations of the extracts for both the sole and intercropped plants. At higher concentrations, disease incidence was low and at lower concentrations, disease incidence was high. At $65 \%$ concentration with extracts of $D$. stramonium, disease incidence for both the sole and intercropped plant were $22.60 \%$ and $14.10 \%$ were compared to the control (100)

At $50 \%$ concentration with extracts of Datura stramonium, disease incidence were $28.50 \%$ and $18.92 \%$ for both sole and intercropped plant compared to extracts of S. acuta at same concentration that gave $31.55 \%$ and $22.50 \%$ respectively. At all the tested concentration, disease incidence in the 
intercropped plant were generally lower than that of sole crop. Significant variations were observed at all the tested concentrations for the extracts used in the study.

Table1. Effect of Plant extracts, concentrations and Intercropping on Incidence of downy mildew of cucumber Inoculated with Pseudoperonospora cubensis in Ado-Ekiti

\begin{tabular}{llll} 
& & \multicolumn{2}{c}{ Disease Incidence \% } \\
Plant extracts & Extract Concentations \% $(\mathrm{w} \mid \mathrm{v})$ & Sole cucumber & Intercropped \\
\hline D. stramonium & & $22.6^{\mathrm{d}}$ & $14.10^{\mathrm{d}}$ \\
& 65 & $28.5^{\mathrm{c}}$ & $18.92^{\mathrm{c}}$ \\
& 50 & $32.7^{\mathrm{b}}$ & $20.11^{\mathrm{b}}$ \\
& 30 & $100^{\mathrm{a}}$ & $100^{\mathrm{a}}$ \\
R. communis & 0 & & $16.15^{\mathrm{c}}$ \\
& 65 & $25.43^{\mathrm{c}}$ & $19.93^{\mathrm{d}}$ \\
& 50 & $30.31^{\mathrm{b}}$ & $21.55^{\mathrm{b}}$ \\
& 30 & $33.70^{\mathrm{b}}$ & $100^{\mathrm{a}}$ \\
S. acuta & 0 & $100^{\mathrm{a}}$ & $18.10^{\mathrm{c}}$ \\
& 65 & & $22.50^{\mathrm{b}}$ \\
& 50 & $26.4^{\mathrm{c}}$ & $22.75^{\mathrm{b}}$ \\
& 30 & $31.55^{\mathrm{b}}$ & $100^{\mathrm{a}}$ \\
Benomy1 & 0 & $34.20^{\mathrm{b}}$ & $11.84^{\mathrm{d}}$
\end{tabular}

Means with the same letter in each column are not significantly different $(\mathrm{P}<0.05)$ (Turkey's HSD)

3.2 Effect of plant extracts, concentration and intercropping on Incidence of normal and abnormal seeds of downy mildew of cucumber inoculated with Pseudoperonospora cubensis

The effect of the plant extracts and concentration on incidence of normal and abnormal seeds of downy mildew of cucumber are shown in table 2. Incidence of normal seeds was generally higher than the abnormal seeds for both sole and intercropped plant. At $50 \%$ concentration with extracts of $R$. communis, incidence of normal seeds for both sole and intercropped plant were $70.18 \%$ and $83.30 \%$ while abnormal seeds were $29.82 \%$ and $16.70 \%$ respectively. Abnormal seeds were generally low at all the tested concentrations.

Table2. Effect of plant extracts on Incidence of normal and abnormal seeds of downy mildew of cucumber caused by Pseudoperonospora cubensis in Ado-Ekiti

\begin{tabular}{|c|c|c|c|c|c|}
\hline \multirow[b]{3}{*}{ Plant extract } & \multirow[b]{3}{*}{ Conc. } & \multicolumn{4}{|c|}{ Incidence of normal and abnormal seeds (\%) } \\
\hline & & \multicolumn{2}{|c|}{ Sole cucumber } & \multicolumn{2}{|c|}{ Cucumber intercropped } \\
\hline & & Normal & Abnormal & Normal & Abnormal \\
\hline \multirow[t]{4}{*}{ D. stramonium } & 65 & $76.77^{\mathrm{a}}$ & $23.23^{\mathrm{d}}$ & $88.95^{\mathrm{a}}$ & $11.05^{\mathrm{d}}$ \\
\hline & 50 & $70.55^{\mathrm{a}}$ & $29.45^{\mathrm{c}}$ & $85.45^{\mathrm{a}}$ & $14.55^{\mathrm{d}}$ \\
\hline & 30 & $68.93^{\mathrm{b}}$ & $31.07^{\mathrm{b}}$ & $83.50^{\mathrm{a}}$ & $16.50^{\mathrm{c}}$ \\
\hline & 0 & $55.40^{\mathrm{c}}$ & $44.60^{\mathrm{a}}$ & $57.30^{\mathrm{c}}$ & $42.70^{\mathrm{a}}$ \\
\hline \multirow[t]{4}{*}{ R. communis } & 65 & $72.45^{\mathrm{a}}$ & $27.55^{\mathrm{c}}$ & $84.75^{\mathrm{a}}$ & $15.25^{\mathrm{c}}$ \\
\hline & 50 & $70.18^{\mathrm{a}}$ & $29.82^{c}$ & $83.30^{\mathrm{a}}$ & $16.70^{\mathrm{c}}$ \\
\hline & 30 & $69.45^{\mathrm{b}}$ & $30.55^{\mathrm{b}}$ & $75.56^{\mathrm{b}}$ & $24.44^{\mathrm{b}}$ \\
\hline & 0 & $53.20^{\mathrm{C}}$ & $46.80^{\mathrm{a}}$ & $54.80^{\mathrm{c}}$ & $45.20^{\mathrm{a}}$ \\
\hline \multirow[t]{4}{*}{ S. acuta } & 65 & $68.50^{\mathrm{b}}$ & $31.50^{\mathrm{b}}$ & $83.77^{\mathrm{a}}$ & $16.23^{\mathrm{c}}$ \\
\hline & 50 & $67.44^{\mathrm{b}}$ & $32.56^{\mathrm{b}}$ & $81.45^{\mathrm{a}}$ & $18.55^{\mathrm{c}}$ \\
\hline & 30 & $64.50^{\mathrm{b}}$ & $35.50^{\mathrm{b}}$ & $79.40^{\mathrm{b}}$ & $20.60^{b}$ \\
\hline & 0 & $52.10^{\mathrm{c}}$ & $47.90^{\mathrm{a}}$ & $53.55^{\mathrm{c}}$ & $46.45^{\mathrm{a}}$ \\
\hline Benomyl & $0.1 \mathrm{~g} /$ litre & $78.44^{\mathrm{a}}$ & $21.56^{\mathrm{d}}$ & $89.94^{\mathrm{a}}$ & $10.06^{\mathrm{d}}$ \\
\hline
\end{tabular}


Means with the same letter in each column are not significantly different $(\mathrm{P}<0.05)$ (Turkey's HSD)

3.3 Effect of Plant extracts, Concentration and Intercropping on seed germination and fungal infection of cucumber Inoculated with Pseudoperonospora cubensis

The effect on seed germination and fungal infection with varying concentrations of plant extracts and intercropping of maize with cucumber inoculated with $P$. cubensis is shown in table 3 . Seed germination was generally low in both cucumbers intercropped with maize and sole plant. Seed germination for sole plant and intercropped cucumber at 50\% concentration with extracts of S. acuta was $22.55 \%$ and $24.52 \%$ respectively compared to the control which was $18.30 \%$ and $18.55 \%$. Fungi infection on the other hand was generally low in sole cucumber and in intercropped plant. At $65 \%$ concentration with the extracts of $D$. stramonium, fungi infection for both sole and intercropped plant were $28.40 \%$ and $16.60 \%$ respectively compared to the control which was $39.75 \%$ and $40.55 \%$.

Table3. Effect of Plant extracts, Concentration and Intercropping on seed germination and fungal infection of cucumber Inoculated with Pseudoperonospora cubensis in Ado-Ekiti

Means with the same letter in each column are not significantly different $(\mathrm{P}<0.05)$ (Turkey's HSD)

S.G $=$ Seed Germination

F.I $=$ Fungal Infection

3.4 Effect of different concentrations of Plant extracts, Intercropping and application of benomyl on the yield of cucumber infected with Pseudoperonospora cubensis

\section{Seed germination/Fungal infection (\%)}

\section{$\underline{\text { Sole cucumber } \quad \text { Cucumber intercropped }}$}

\begin{tabular}{llllll} 
Plant extracts & \multicolumn{1}{l}{ Conc. $(\% \mathrm{w} / \mathrm{v})$} & S.G & F.I & S.G & F.I \\
\hline D. stramonium & 65 & $20.55^{\mathrm{a}}$ & $28.40^{\mathrm{c}}$ & $21.60^{\mathrm{b}}$ & $16.60^{\mathrm{c}}$ \\
& 50 & $18.40^{\mathrm{b}}$ & $26.30^{\mathrm{c}}$ & $22.75^{\mathrm{b}}$ & $16.40^{\mathrm{c}}$ \\
& 30 & $19.55^{\mathrm{b}}$ & $25.50^{\mathrm{c}}$ & $22.40^{\mathrm{b}}$ & $18.50^{\mathrm{b}}$ \\
R. communis & 65 & $22.64^{\mathrm{a}}$ & $29.40^{\mathrm{c}}$ & $22.77^{\mathrm{b}}$ & $17.72^{\mathrm{b}}$ \\
& 50 & $19.60^{\mathrm{b}}$ & $30.20^{\mathrm{b}}$ & $21.55^{\mathrm{b}}$ & $19.10^{\mathrm{b}}$ \\
& 30 & $20.15^{\mathrm{a}}$ & $31.10^{\mathrm{b}}$ & $22.67^{\mathrm{b}}$ & $18.92^{\mathrm{b}}$ \\
S. acuta & 65 & $21.11^{\mathrm{a}}$ & $30.25^{\mathrm{b}}$ & $22.30^{\mathrm{b}}$ & $15.56^{\mathrm{c}}$ \\
& 50 & $22.55^{\mathrm{a}}$ & $31.95^{\mathrm{b}}$ & $24.52^{\mathrm{a}}$ & $17.71^{\mathrm{b}}$ \\
& 30 & $19.45^{\mathrm{b}}$ & $32.12^{\mathrm{b}}$ & $23.91^{\mathrm{a}}$ & $19.20^{\mathrm{b}}$ \\
& 0 & $18.30^{\mathrm{b}}$ & $39.75^{\mathrm{a}}$ & $18.55^{\mathrm{c}}$ & $40.55^{\mathrm{a}}$ \\
Benomyl & $0.1 \mathrm{~g} /$ litre & $24.35^{\mathrm{a}}$ & $24.60^{\mathrm{c}}$ & $23.20^{\mathrm{a}}$ & $15.60^{\mathrm{c}}$
\end{tabular}

Means with the same letter in each column are not significantly different $(\mathrm{P}<0.05)$ (Turkey's HSD)

The effect of plant extracts, intercropping, and application of benomyl on yield of downy mildew infected cucumber is shown in table 4 . Yield of cucumber varies with the concentration of the extracts for both the sole and intercropped plants. At lower concentrations of the extracts, yield was relatively low and at higher concentrations, yield was generally high. At $65 \%$ concentration with extracts of $D$. stramonium, yield for sole cucumber were significantly different while that of intercropped cucumber was not. However, at lower concentrations of the extracts, yield of benomyl treated plots was higher than extract sprayed plots.

Table4. Effect of different concentrations of Plant extracts and benomyl on the yield of cucumber infected with Pseudoperonospora cubensis in Ado-Ekiti 


\begin{tabular}{llll}
\hline & & \multicolumn{2}{c}{ Yield $(\mathrm{kg} / \mathrm{ha})$} \\
Plant extracts & Extract Concentations $\%(\mathrm{w} / \mathrm{v})$ & Sole cucumber & Intercropped \\
\hline D. stramonium & 65 & $310^{\mathrm{a}}$ & $345^{\mathrm{a}}$ \\
& 50 & $278^{\mathrm{b}}$ & $321^{\mathrm{a}}$ \\
& 30 & $250^{\mathrm{b}}$ & $300^{\mathrm{a}}$ \\
R. communis & 0 & $140^{\mathrm{c}}$ & $145^{\mathrm{c}}$ \\
& 65 & $271^{\mathrm{b}}$ & $320^{\mathrm{a}}$ \\
& 50 & $268^{\mathrm{b}}$ & $296^{\mathrm{b}}$ \\
S. acuta & 30 & $256^{\mathrm{b}}$ & $285^{\mathrm{b}}$ \\
& 0 & $142^{\mathrm{c}}$ & $140^{\mathrm{c}}$ \\
& 50 & $278^{\mathrm{b}}$ & $315^{\mathrm{a}}$ \\
& 30 & $256^{\mathrm{b}}$ & $288^{\mathrm{b}}$ \\
Benomyl & 0 & $240^{\mathrm{b}}$ & $275^{\mathrm{b}}$ \\
& $0.1 \mathrm{~g} /$ litre & $142^{\mathrm{c}}$ & $140^{\mathrm{c}}$ \\
\hline
\end{tabular}

\section{DISCUSSION}

In the study, leaves of Datura stramonium, Ricinus communis and Sida acuta were powdered and tested against Pseudoperonospora cubensis, the pathogen causing downy mildew of cucumber at various concentrations and their efficacy was concentration dependent. The leaf extracts were collected, air-dried and powdered so as to offer a higher surface area for the reaction. It has been observed that air-dried leaf extracts are better than sun-dried ones because the chemistry of the constituents are well preserved (Vongsak et al., 2013). Enyiukwu and Awurum (2013) reported that variations in concentrations of bioactive components in plant extracts are known to be influenced by the method of extraction, age of plants at harvest, time of harvesting and mode of exposure of plant to air. Hot water extraction was employed in this study because it is capable of preserving the active ingredients in the extract, also the method is cheap and can easily be transferred to resource poor farmers as a way of combating the problem of plant diseases

In this study, the plant extracts were tested at various concentrations on the incidence of the disease, result from the study shows that incidence of the disease were relatively lower where higher concentration of the plant extracts were used and significant variations exist among all the plant extracts used in the study compared to the control. Severity of infection in extract sprayed plot was characterized by the presence of small lesion only on the lower leaves of the cucumber plant while the control plot was characterized with advanced lesions on leaves and fruits. This may be due to the presence of fungi static chemicals in the extracts. The result obtained is in agreement with the work of (Jimoh, et al., 2016) who reported that incidence of Cercospora species and fusarium species were significantly reduced on seed sprayed with extract of Chromolaena odoratum and Tithonia diversifolia. The report also indicated that lower number of abnormal seeds was recorded in the intercrop plot than in the control.

The effect of intercropping maize with ccumber showed that the incidence and severity of downy mildew of cucumber were less in the intercrop than in sole cucumber. Intercropping has been reported to alter the response of host plant and pathogens to changes in the environment and this generates diverse alterations in the ecosystem which may be responsible for reduced incidence of infection. The result obtained in this study is in line with the work of (Enikuomehin et al., 2008) who reported that the incidence and severity of foliar disease of sesame (Sesanum indicum) was reduced when intercropped with maize and sprayed with the extracts of Ocimum gratissimum. Apart from this, intercropping tends to reduce the speed of wind which invariably reduces air circulation and hence, reduction in the rate of inoculums transfer (Enikuomehin, 2007)

In this study, Incidence of normal seeds were generally higher than the abnormal seeds for both sole and intercropped plant at all the tested concentrations of plant extracts used in the study. Abnormal seeds were generally low at all the tested concentrations and significant $(\mathrm{P}<0.05)$ variations were observed in all the treatments used. This study agrees with the work of Falade 2018 who reported that Incidence of normal seeds were relatively higher than abnormal seeds when extracts of $R$. communis 
and D. stramonium were used in the control of Collectotrichum lindemuthanum causing anthracnose disease of cowpea.

In this study, seed germination was generally low in both cucumbers intercropped with maize and the sole plant and there was no significant difference. Seed germination for sole plant at $50 \%$ concentration of S. acuta was $22.55 \%$ while that of intercropped was $24.52 \%$. Fungi infection on the other hand were generally low. At $65 \%$ concentration with the extracts of $D$. stramonium, fungi infection for both sole and intercropped were $28.40 \%$ and $16.60 \%$ respectively. This study agrees with the work of Amadioha 2003 who reported that seed germination and fungi infection were low when extracts of $A$. indica was used to control $C$. gloeosporioides causing papaya anthracnose.

In this study, significant variations were observed on yield of cucumber when extracts of the three plants were compared with benomyl fungicide. The yield of cucumber plots sprayed with extracts of D. stramonium at $65 \%$ concentration was not significantly different from the yield of cucumber plots sprayed with benomyl fungicides. However, variations were observed at lower concentrations of plant extracts such that yield of cucumber plots treated with benomyl fungicides were generally higher than that of other extracts used in the study. This report agrees with the work of Falade 2018 who reported that yield of cowpea sprayed with extracts of D. stramonium at $65 \%$ concentration was not significantly different from that of benomyl treated plots. However, at lower concentration of the extracts, yield of benomyl treated plot were better than that of other extracts. Similarly, Enyiukwu and Awurum (2013) reported the control of cowpea anthracnose caused by Collectotrichum destructivum $O$. Gara using extracts of Carica papaya roots and seeds alongside the use of benomyl, the study shows that papaya extract compared favourably with benomyl in fungitoxicity to the pathogen which is in agreement with this study.

\section{CONCLUSION AND RECOMMENDATION}

This research provided information that cucumber downy mildew can be controlled with the use of plant extracts on the field in combination with intercropping. Extracts of D. stramonium, S. acuta, $R$. cummunis have potential to inhibit the growth of the pathogen that causes the disease and the development. These plant materials are readily available around homesteads while the method of extraction is relatively simple. Based on this research work, the leaf extracts at $50 \%$ and $65 \%$ concentration used in the study are recommended for the control of downy mildew of cucumber. Similarly, cucumber should be intercropped with maize combined with foliar application of extract to reduce the incidence of downy mildew. This will provide a viable alternative to the use of fungicide which often is costly.

\section{REFERNCES}

[1] Adedipe, A. O. (2017): Yield and Post Harvest Qualities of Cucumber as Influenced byCompanion Planting. Unpublished thesis submitted to the Department of Crop Science and Horticultulture, Federal University of Agriculture, Oye Ekiti, Nigeria

[2] Ademe, A., Ayalew, A. and Woldetsadik, K. (2013). Evaluation of Antifungal activity of plants extracts against Papaya Anthracnose (Collectotrichum gloeosporioides). Journal of plantPathology and Microbiology 4: 10-14.

[3] Alves, K. F., Laranjeira, D., Camara, M.P, S.J. (2015). Efficacy of Plant extracts for Anthracnose Control in Bell pepper Fruits under controlled conditions. Horticultural Brasileira 33: 332-338.

[4] Amadioha, A.C. (2003). Evaluation of some plant leaf extracts. ActaPhytopathologica.Hungaria 38: 3-6.

[5] Awurum, A. N and Enyiukwu D. N 2013. Evaluation of seed-dressing potentials of phytochemicals from Carica papaya and Piper quinensence on the germination of cowpea (Vigna unquiculata. (L.) Walp) seeds and Incidence of the seed-borne Fungi. Continental Journal of Agricultural Science 7 (I): 29-35.

[6] Enikuomehin, O.A., Aduwo, A.M., Olowe and Oduwaye, O.A. (2008).Incidence and Severity of Foliar Diseases of Sesame (Sesamumindicum L) Intercropped with Maize (Zea mays L.)Archives of Phytopathology and Plant Protection 43: 972-986.

[7] Enyiukwu and Awurum. (2013) The control of cowpea anthracnose caused by Collectotrichum destructivum O. Gara using extracts of Carica papaya roots and seeds alongside the use of benomyl. International Journal Advances in Agriculture 56: 455-457 
[8] Falade, M. J (2018): Use of Hot Water Extracts of some Intercropping in the Management of Cowpea anthracnose caused by Colletotrichum lindemothianum. Ph.D thesis submitted to the Department of Crop Protection, Federal University of Agriculture, Abeokuta, Nigeria.

[9] FAO, "Food and Agricutural Organization of the United Nations" (2000) FAOSTAT Agricultural Data. http://apps.fao.org/lim500/nphwrap.pl?production.crops.primary.

[10]FAOSTAT.(2017). Food and Agriculture Organisation of the United Nations. Site internet: http//www.fao.org/statistics.

[11] Jeffery, C. (2001). Cucurbitaceace In: P. Hanett (ed.), Mansfeld's Encyclopedia of Agricultural and Horticultural Crops31: 1550-1557. Springer-verlag, Berlin Herdelberg.

[12] Lowell, J.F. (2004). Producing food without pesticide.Editors Macmillan Publishers. 22pp Natural News (2014). 10 Health benefits of cucumbers http://www.naturalnews.com/036769_cucumbers_ health_benefits_rehydration.html.

[13] Nor-farah, L. A, Sifi, H. R, Azizal, M. S and Norfhairna, B (2018): Effect of PH on growth Rate and Yield of Cucumis Sativus. Journal Halian Association of Chemical Engineering. Vol. 63: pp. 978-988

[14] Vongsak B, Sithisam P, Mangmool S, Thongpraditchote S, Wonkkrajang Y, (2013): Maximizing total phenolics, total flavonoids contents and antioxidant activity of Moringaoleifera leaf extract by the appropriate extraction method Ind. Crops Production 44: 566-571

[15] Wasila, L.A.,Correll, J.C,Morelock ,T.E, andMcNew,R.E (1993). Reexamination of races of the cucurbit anthracnose pathogen Colletotrichumorbiculare. Phytopathology 83:1190-1198.

[16]Zivkovic, S., Stojanovic, S., Ivanovic, Z, Trkulja, N., Dolovac, N., Aleksic, G., and Balaz, J. (2010).Morphological and molecular identification of tomato fruit disease.Pesticidifitomedicina 25 (3): 2-8.

Citation: M. J Falade., (2021). "Management of Cucumber Downy Mildew Caused by Pseudoperonospora Cubensis with use of Benomyl, Plant Extracts and Intercropping.", International Journal of Research Studies in Agricultural Sciences (IJRSAS), 7(6), pp. 25-32 DOI: http://dx.doi.org/10.20431/2454-0706004.

Copyright: (C) 2021 Authors. This is an open-access article distributed under the terms of the Creative Commons Attribution License, which permits unrestricted use, distribution, and reproduction in any medium, provided the original author and source are credited. 